\title{
The Long Arm of Long Noncoding RNAs: Roles as Sensors Regulating Gene Transcriptional Programs
}

\author{
Xiangting Wang ${ }^{1}$, Xiaoyuan Song ${ }^{1}$, Christopher K. Glass ${ }^{2}$, and Michael G. Rosenfeld ${ }^{1}$
}

${ }^{1}$ Howard Hughes Medical Institute, School and Department of Medicine, University of California, San Diego School of Medicine, La Jolla, California 92093-0651

${ }^{2}$ Cellular and Molecular Medicine and Department of Medicine, University of California, San Diego School of Medicine, La Jolla, California 92093-0651

Correspondence: mrosenfeld@ucsd.edu

\section{SUMMARY}

A major surprise arising from genome-wide analyses has been the observation that the majority of the genome is transcribed, generating noncoding RNAs (ncRNAs). It is still an open question whether some or all of these ncRNAs constitute functional networks regulating gene transcriptional programs. However, in light of recent discoveries and given the diversity and flexibility of long ncRNAs and their abilities to nucleate molecular complexes and to form spatially compact arrays of complexes, it becomes likely that many or most ncRNAs act as sensors and integrators of a wide variety of regulated transcriptional responses and probably epigenetic events. Because many RNA-binding proteins, on binding RNAs, show distinct allosteric conformational alterations, we suggest that a ncRNA/RNA-binding protein-based strategy, perhaps in concert with several other mechanistic strategies, serves to integrate transcriptional, as well as RNA processing, regulatory programs.

\section{Outline}

1 Introduction

2 Characterization of long ncRNAs

3 Long ncRNA-dependent recruitment of protein complexes

4 Mechanisms mediating transcriptional regulation by long ncRNAs
5 Biological roles of long ncRNAs

6 Conclusions and perspectives

References

Editors: John F. Atkins, Raymond F. Gesteland, and Thomas R. Cech

Additional Perspectives on RNA Worlds available at www.cshperspectives.org

Copyright (C 2011 Cold Spring Harbor Laboratory Press; all rights reserved; doi: 10.1101/cshperspect.a003756

Cite this article as Cold Spring Harb Perspect Biol 2011;3:a003756 


\section{INTRODUCTION}

Although the roles of cognate elements for DNA binding proteins and assorted coactivators and corepressors in organizing and encoding patterns of transcriptional responses are well established (Reviewed in Rosenfeld et al. 2006), the discovery that a huge percentage of the genome is transcribed into noncoding RNAs (ncRNAs), has presented the challenge of determining whether there is a vast functional network of ncRNAs that might regulate gene transcriptional programs (Bertone et al. 2004; Carninci et al. 2005; Cheng et al. 2005; Johnson et al. 2005; Katayama et al. 2005; Carninci et al. 2006; Gustincich et al. 2006; Willingham and Gingeras 2006).

The critical roles of some classes of small ncRNAs (reviewed in Chu and Rana 2007; Kutter and Svoboda 2008; Choudhuri 2009) are beginning to emerge; however, the broad spatial distribution of long ncRNA expression, often at remarkably low levels, has itself raised the challenge to delineate the mechanisms underlying their transcription, regulation, and potential functional roles. The basic questions of "who, when, what, where, and how" are still incompletely defined. Here, we will attempt to organize some of the rapidly expanding information regarding the long ncRNAs, focusing on their roles in transcriptional regulation of nonimprinted genes.

Based on a overview of the cumulative data in the literature regarding ncRNAs, we propose that ncRNAs use several mechanisms to exert important regulatory functions in the control of transcriptional programs (Fig. 1). This large number of ncRNAs have the inherent flexibility to function in "nucleating" molecules for combinatorial complex assembly, ideal for functioning as "sensors" and integrators for a variety of developmental and physiological signals. The alternative recruitment of "corepressors," "coactivators," and DNA-modifying complexes in various combinations might additionally be dictated by alterations in strandedness, transcriptional length, or splicing of ncRNAs, functionally modulating their biological actions. We suggest that most of the functions of long ncRNAs relate to their interactions with RNA-binding proteins, most of which contain multiple RNA-binding domains that may recognize distinct "targets." This implies that many RNAbinding proteins might, as a consequence, show distinct "allosterically dictated" conformations based on the specific RNA sequences they bind-in a sense RNAs would be analogous to the effect of distant "ligands" on nuclear receptors (Glass and Rosenfeld 2000; McKenna and O’Malley 2002). Given that RNA-binding proteins constitute the largest "transcriptional" regulatory family in the genome (Burd and Dreyfuss 1994; Lunde et al. 2007), such an ncRNA/RNA-binding protein-based strategy to integrate transcriptional programs is very likely a general rule in the transcriptional as well as RNA processing regulation. Taken together, the ncRNA sensor code appears to be a robust and critical strategy underlying a wide variety of gene regulatory programs.

\section{CHARACTERIZATION OF LONG NCRNAS}

\section{Classification}

Compared with small ncRNAs (Montgomery and Fire 1998; Grishok and Mello 2002; Ambros 2001; Aravin et al. 2006; Girard et al. 2006; Grivna et al. 2006; Lau et al. 2006; Vagin et al. 2006; Watanabe et al. 2006; Amaral and Mattick 2008; Lee et al. 2009), long ncRNAs are often arbitrarily considered as $>200 \mathrm{nt}$ and include long ncRNAs implicated in dosage compensation and imprinting. The most recently identified long ncRNAs in transcriptional regulation of nonimprinted genes are usually shorter than $10 \mathrm{~kb}$. These long ncRNAs can be grouped into a remarkably diverse set of transcripts. One classification has been based on abundance, i.e., the "high abundance" (such as NEAT1 and NEAT2; Hutchinson et al. 2007) and "low abundance" long ncRNAs (such as CCND1ncRNA; Wang et al. 2008a). Another classification is by function, i.e., "cis-acting" and "trans-acting" long ncRNAs. The conservative estimated number of long ncRNAs is $\sim 17,000$ in the human and $\sim 10,000$ in the mouse genome (www.Invitrogene.com). The number is likely to be greatly underestimated, especially, because many primary transcripts are often processed into smaller ncRNAs.

\section{Strandedness}

Long ncRNAs can be expressed from either or both DNA strands. Sense-antisense pairing between ncRNAs from two DNA strands has been observed in some cases. For example, massive sense-antisense pairing transcripts are found in Alu repeats (Wang et al. 2008b) and UTRs of protein coding genes (Kapranov et al. 2007). The significance of forming a double-stranded (ds) ncRNA is not clear. However, a ds ncRNA will lose the ability to pair with its complementary RNA or DNA sequence. Therefore, we hypothesize that the formation of a ds ncRNA may often act to block/regulate at least some functions of singlestranded (ss) ncRNAs. However, this does not exclude the possibility that ds ncRNAs form to change their affinity for RNA-binding proteins.

\section{Subcellular Localization}

In contrast to most mRNAs, which ultimately localize to the cytoplasm after processing, most long ncRNAs are 

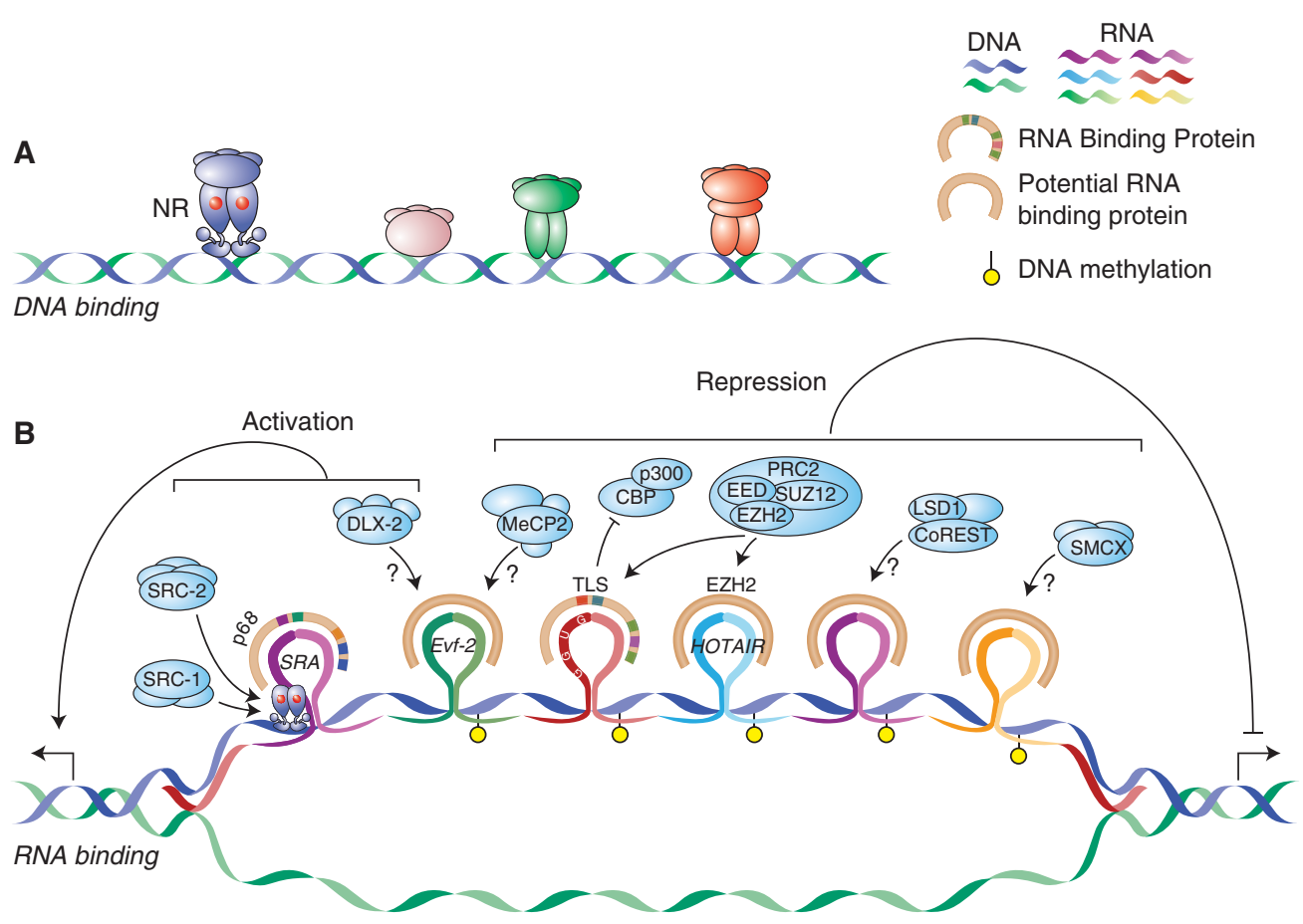

Figure 1. NcRNA-protein network in gene transcription program regulation. Comparing with the well-established DNA-transcriptional factor network $(A)$, the ncRNA-protein network $(B)$ provides a flexible platform capable of acting as sensors for various signals, integrating multiple regulatory complexes. In cis and in trans ncRNAs may work synergistically to recruit protein complexes involved in transcription regulation via RNA-binding proteins, as a bridge, to serve as a combinatorial DNA and histone modification code, altering chromosomal architecture.

permanently localized in the nucleus, including polyAnegative long ncRNAs that account for a large portion of the total transcribed sequences ( $\mathrm{Wu}$ et al. 2008) and long ncRNAs transcribed from intronic regions (Cheng et al. 2005). A subset of long ncRNAs is located in both the nucleus and the cytoplasm (Imamura et al. 2004; Cheng et al. 2005; Kapranov et al. 2007; Wu et al. 2008). There are also some long ncRNAs selectively localized in the cytoplasm (Louroa et al. 2009).

\section{Regulation/Processing}

The tissue-/organ-specific expression patterns of many long ncRNAs in development, and the distinct subcellular localization of long ncNRAs, strongly suggest that their expression is under precise control (Amaral and Mattick 2008; Dinger et al. 2008; Mercer et al. 2008). Although some long ncRNAs have been reported to be transcribed by RNA polymerase III (Pol III) (Liu et al. 1995; Nguyen et al. 2001; Yang et al. 2001; Dieci et al. 2007), the majority are transcribed by RNA polymerase II (Pol II). However, it remains largely unknown how long ncRNAs are regulated at the level of their transcription and/or processing. For the $\sim 1600$ more abundant (conserved mammalian) long ncRNAs (Guttman et al. 2009; Khalil et al. 2009), it is reported that the basic "rules" are analogous to those of conventional Pol II transcription units: having histone H3K4 trimethylation mark at their promoters and H3K36 trimethylation marks within transcription body, and forming the so-called chromatin signature of the K4-K36 domain (Fig. 2A) and having a 5' CAP site (Fig. 2B). Moreover, several well-known transcription factors for coding mRNA genes are also found to be present on a large number of ncRNA transcription units (Martone et al. 2003; Cawley et al. 2004; Kim et al. 2005). Other reported factors include Cha4, SAGA and Swi/Snf in Saccharomyces cerevisiae and REST in mammalian cells (Reviewed in Neurosci Letter 2009. Aug 11, Epub ahead of print). A central question for those ncRNAs that do not show the conventional $\mathrm{H} 3$ trimethylation of $\mathrm{K} 4$ and $\mathrm{K} 36$ marks and the Cap site (Fig. 2C) is whether this reflects processing from very long ncRNA transcripts that do harbor such sites at their transcription origins, or represents an alternative transcriptional regulatory strategy, such as polymerase entry at nicked sites.

Long ncRNAs are often spliced (Fig. 2D) and appear to use mechanisms similar to those used for miRNA processing. For example, we found that knock-down of the miRNA regulator DROSHA, but not DICER, increased the expression level of CCND1ncRNA about four-fold (TW, XS and 
X. Wang et al.
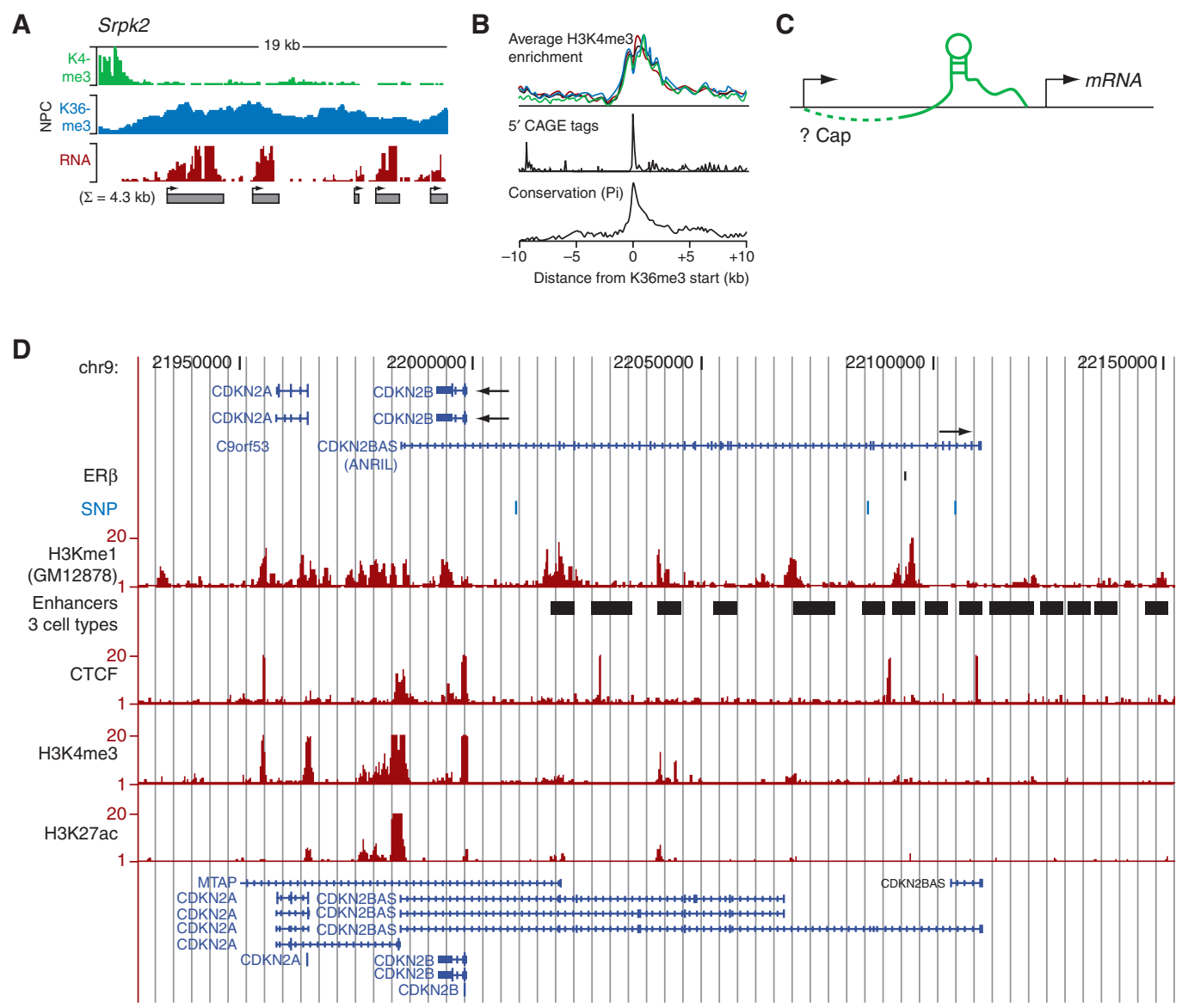

Figure 2. Characterization of long ncRNAs. (A) Long ncRNAs can be generated from intergenic K4-K36 domains as exemplified by the Srpk2 intergenic long ncRNAs, which were identified by hybridizing RNA to DNA tiling arrays (Adopted from Guttman et al. 2009). (B) Expression of promoter-associated long ncRNAs can be identified by their correlation to H3K4 me3 and CAGE-tag (Adopted from Guttman et al. 2009). (C) Some long ncRNAs have no apparent Cap site been identified (such as the CCND1ncRNAs). (D) Some long ncRNAs are processed by splicing such as the disease loci in CDKN2BAS (ANRIL; Pasmant et al. 2007).

MGR, unpublished data), suggesting that CCND1ncRNA may be processed in a DROSHA-dependent manner.

\section{LONG NCRNA-DEPENDENT RECRUITMENT OF PROTEIN COMPLEXES}

One critical function of many, if not all, ncRNAs would appear to reside in their ability to interact with specific regulatory proteins/protein complexes, probably usually involving members of the large families of RNA-binding proteins. Because of RNA sequence and structural flexibility, ncRNAs are well-suited to accommodate binding of multiple complexes. Indeed, many ncRNAs associate with proteins and form complexes that function as a unit, as exemplified by the RNA Pol III-transcribed ribosome, RNA-induced silencing complex (RISC), and signal recognition particle (the conserved SRP, protein-RNA complex;
Batey et al. 2000; Storz 2002). As more and more ncRNAs have been discovered, some generalized rules regarding potentially associated protein complexes are beginning to be discerned.

Studies from several groups suggested a critical role of long ncRNAs in epigenetic regulation by orienting chromatin-modifying factors/complexes to specific locations in the genome and in the nucleus (Sanchez-Elsner et al. 2006; Rinn et al. 2007; Chen et al. 2008; Zhao et al. 2008; Khalil et al. 2009). Initially described factors/complexes that are recruited by long ncRNAs include Ash1 by TRE1-3 (Sanchez-Elsner et al. 2006) and MSL/MSL2 by roX RNA (Li et al. 2008; and reviewed in Scott and Li 2008) in Drosophila; the SRC1 complex by SRA (Lanz et al. 1999), PRC1 and PRC2 complexes by Xist (Plath et al. 2002; de Napoles et al. 2004; Schoeftner et al. 2006), PRC2 complex by HOTAIR and RepA (Rinn et al. 2007; Zhao 
et al. 2008), G9a by Air (Nagano et al. 2008), and TLS/CBP/ p300 complex by CCND1ncRNA (Wang et al. 2008) in mammalian cells. Recently, a genome-wide ChIP-RNA sequencing analysis found that up to $38 \%$ of the $\sim 3300$ conserved large intergenic ncRNAs are associated with one of the following four chromatin-modifying factorsEZH2, SUZ12, CoREST, and JARID1C/SMCX (Khalil al. 2009). Besides, the homeodomain protein Dlx-2 has been shown to be recruited to the intergenic enhancer region of Dlx-5 and Dlx-6 via a brain specific ncRNA, Evf2 (Feng et al. 2006).

It is very interesting that most of the reported long ncRNAs-associated proteins are chromatin-modifying factors. Other chromatin/histone-modifying factors, such as LSD1, a component of the CoREST complex (Shi et al. 2005), are likely to combinatorialy impose strong effects as well. We propose that the complexity and diversity of ncRNAs promote the formation of chromatin-modifying complexes to establish the "epigenetic" memory. Despite the fact that most of the reported ncRNA-associated chromatin-modifying complexes are involved in gene repression, we suggest that an equally large numbers of long ncRNAs can recruit coactivator complexes, including components of the trithorax/COMPASS/MLL complex (Beisel et al. 2007; Schuettengruber et al. 2007; Shilatifard 2008). An immediate question is how regulatory ncRNAs recruit protein complexes. One possibility is that ncRNAs form RNA:RNA or RNA:DNA structures, which provide sequence specificity and serve as platforms to bind proteins that are not strictly sequence-specific, and thus directing these proteins to target sites (Mattick and Gagen 2001; Mattick 2007). It is also possible that ncRNAs can alter their structure on "ligand" binding and function as "riboswitches" (Wickiser et al. 2005; St Laurent and Wahlestedt 2007). It will be of interest to explore more open questions as: How many distinct complexes are recruited to various ncRNAs? What are the combinatorial "programs" of multiple coregulator complexes that might be required for maintaining epigenetic memory?

\section{MECHANISMS MEDIATING TRANSCRIPTIONAL REGULATION BY LONG NCRNAS}

Given their widespread distribution, long ncRNAs are likely to play roles in gene repression and/or activation, acting as sensors of various regulatory signals. The central strategy is the use of epigenetic regulation, including histone and DNA methylation, and many other posttranslational modifications and remodeling complexes. In addition, long ncRNAs can affect the loading of general transcription factors as well as polymerase, or modulate the activities of specific transcription factors.
Serving as Ligands or Cofactors to Mediate Histone Modification

\section{$S R A$}

Nuclear receptors (NRs) comprise a super family of liganddependent transcription factors that regulate metabolism, development and reproduction (reviewed in Glass and Rosenfeld 2000; McKenna and O’Malley 2002). It has been well-established that the activities of NRs are mediated by the ligand-dependent exchange of coactivators and corepressors, which were initially thought to all be proteins. The finding that an ncRNA, SRA, functions as a coactivator (Lanz et al. 1999) significantly expanded concepts of mechanisms enabling transcriptional coactivation. SRA coactivates a range of NRs, including ER, AR, GR, PR, RAR $\alpha, \operatorname{PPAR} \delta$ and $\gamma, \mathrm{TR}$, and VDR (Lanz et al. 1999; Deblois and Giguere 2003; Kawashima et al. 2003; Zhao et al. 2004; Hatchell et al. 2006), and some other classes of transcription factors, such as MyoD (Caretti et al. 2006). SRA has multiple stem-loops and a series of mutational studies showed that discrete stem-loops are required for the coactivator activity of SRA. Many SRA-associated RNA-binding proteins have been found to either positively or negatively regulate the coactivator activity of SRA. For example, the coactivator activity of SRA on Myo D is augmented in the presence of DEAD boxcontaining RNA-binding proteins p68 and p72 (Caretti et al. 2006). In the absence of ligand, SRA is sequestered by the transcriptionally silent $\mathrm{TR} \alpha 2$ to a repressive protein complex containing RNA-binding proteins SHARP and SLIRP (Shi et al. 2001; Hatchell et al. 2006). SHARP and SLIRP repress the activities of a range of NRs through the recruitment of HDAC and NCoR/SMRT (Shi, Downes et al. 2001; Hatchell, Colley et al. 2006). When the ligand is present, $S R A$ is released from TR $\alpha 2$ and switches between binding corepressor complexes and binding coactivator complexes (e.g., SRC1 and SRC2; Xu and Koenig 2004; $\mathrm{Xu}$ and Koenig 2005).

\section{Evf2}

Another example for a long ncRNA serving as a transcription coactivator/corepressor is Evf2 in the developing mouse forebrain. Evf2 is a long, polyadenylated ncRNA transcribed from an ultraconserved intergenic enhancer region associated with the $D l x-5 / 6$ locus (Feng et al. 2006) (Fig. 3A). The Dlx genes are related to the Drosophila Distalless gene ( $\mathrm{dll}$ ) homeodomain-containing protein family, and play crucial roles in neuronal development. Ei and eii are intergenic enhancers identified from $D l x-5 / 6$ loci, regulated by homeodomain protein Dlx-2. Evf2 is transcribed from the Ei region and its expression is highly correlated 
X. Wang et al.

A
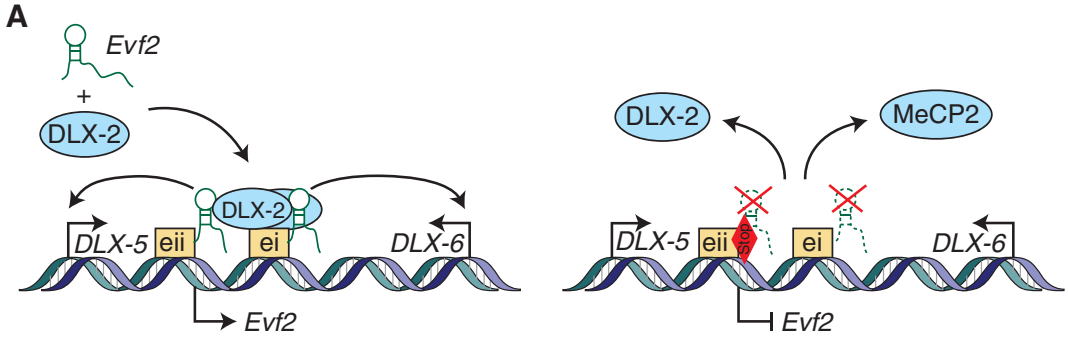

B

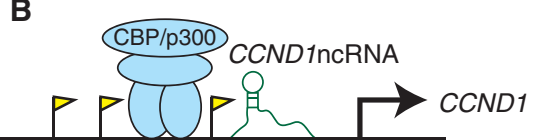

C
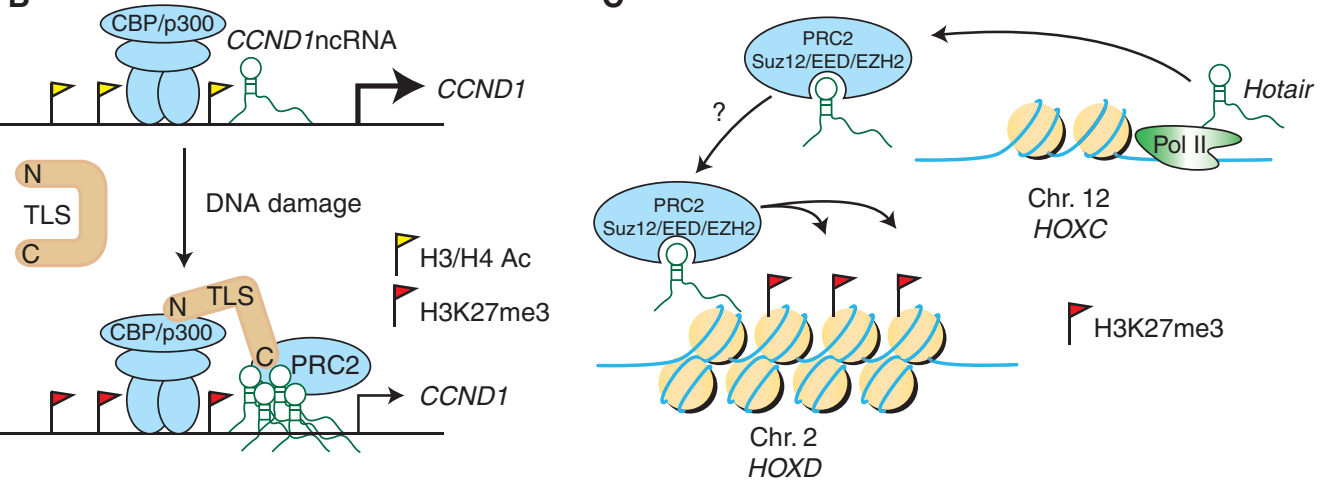

Figure 3. NcRNAs act as co-factors or ligands to regulate transcription. (A) A brain-specific ncRNA, Evf2 is generated from an intergenic enhancer region of $D L X-5 / D L X-6$ and promotes the enhancer activity via recruitment of homeodomain protein DLX-2 (Left). Both DLX-2 and MeCP2 are dismissed from the intergenic enhancer region when the expression of Evf2 is disrupted (Right). (B) Low-copy numbered CCND1ncRNAs are induced on DNA damage and in cis recruit an RNA-binding protein, TLS to inhibit the CCND1 mRNA expression via inhibiting the HAT activities of CBP/p300. PRC2 complex is recruited to the CCND1 5' regulatory region via TLS. (C) HOTAIR generated from HOXC on Chr. 12, acts in trans on HOXD on Chr. 2 to repress the gene expression via recruitment of PRC2 complex.

with the expression of $D l x-5$ and -6 . Evf2 forms a complex with Dlx-2 and recruits Dlx-2 to induce the enhancer activities of ei and eii, resulting in induced expression of both Dlx-5 and -6. These data suggest that the Evf2 ncRNA functions as a coactivator molecule, analogous to the functions of SRA.

Evf2-null mice were generated by inserting transcription stop sites into Evf exon 1 (Bond et al. 2009). ChIP analysis on these Evf2-null mice revealed that both Dlx and $\mathrm{MeCP} 2$, a previous known repressor of $D l x-5$, are dismissed from ei and eii. MeCP2-mediated repression is suggested to be through the recruitment of HDACs. The binding of HDACs, however, is not changed in the absence of MeCP2 in Evf2-null mice. Surprisingly, the levels of Dlx-5 and -6 transcripts increased in Evf2-null mice. It is unclear how Dlx-5 and -6 are transcribed in the absence of Dlx binding. It is possible that Dlx proteins may only be required for initial activation of $D l x-5 / 6$ in an Evf2independent manner, whereas subsequent regulation of Dlx-5/ 6 by Dlx and MeCP2 is Evf2-dependent. Alternatively, other Dlx-binding sites compensate in the absence of Dlx-ei/eii interactions; or the major role of Dlx proteins is to prevent repressors such as MeCP2 from binding ei/eii, rather than acting as direct activators.

\section{CCND1 nCRNA}

Promoter-associated ncRNAs can function as ligands to mediate histone modifications, exemplified by our study of CCND1ncRNA and members of the TET RNA-binding protein family, including TLS, EWS, and TAFII68 (Wang et al. 2008) (Fig. 3B). TLS, translocated in liposarcoma, is an RNA-binding protein with RNA-binding domains at its C-terminus. These RNA-binding domains are frequently deleted in human tumors in which the amino terminus of TLS is fused with other transcriptional factors, suggesting an important role of RNA-binding domains of TLS in human disease. The amino-terminal glutaminerich domain of TLS, on the other hand, is responsible for the interaction with two well-known histone acetyltransferases, CBP and p300. The interaction between TLS and $\mathrm{CBP} / \mathrm{p} 300$ results in the substrate-specific inhibition of the HAT activities of CBP/p300 (Wang et al. 2008). We reported that a series of ncRNAs (CCND1ncRNAs) are generated from the $5^{\prime}$ regulatory regions of CCND1. The $C C N D 1$ ncRNAs are upregulated in response to genotoxic stress, when the CCND1 mRNA is down-regulated. The induction the CCND1ncRNAs recruit TLS and cause a close-to-open conformation change in TLS that licenses 
its amino-terminal binding of $\mathrm{CBP} / \mathrm{p} 300$, resulting in substrate-specific inhibition of their HAT enzymatic activities, and thus establishing the hypo-acetylation status of the chromatin and repressing of the CCND1 mRNA expression. Surprisingly, these CCND1ncRNAs are at very low abundance (two to eight copies/cell) and are associated with chromatin, functioning in cis as ss RNAs to recruit and modulate the activity of TLS. Interestingly, these ncRNAs appear to facilitate the recruitment of PRC1 and PRC2 complexes as well (Fig. 1) (TW, XS, BS, and MGR, unpublished data). In combination with our preliminary data that TLS binds to the EZH2 complex (BS, TW, XS, and MGR, unpublished data), it further suggested that TLS might be required for the recruitment of EZH2 to CCND1 promoter during repression.

\section{HOTAIR}

HOX genes are a group of genes that control the anteriorposterior axis and segmentation during development. Humans contain four clusters of HOX genes, HOXA on chromosome 7, HOXB on chromosome 17, HOAC on chromosome 12, and HOXD on chromosome 7 (Wellik 2009). Tiling arrays covering all four human HOX clusters identified 231 novel ncRNAs, which are spatially expressed along developmental axes and show distinct histone methylation patterns (Rinn, Kertesz et al. 2007). Among these, a $2.2 \mathrm{~kb}$ long ncRNA, HOTAIR, transcribed from the boundary of two diametric chromatin domains in the HOXC locus was preferentially expressed in posterior and distal sites. HOTAIR recruits PRC2 complex in trans across 40 $\mathrm{kb}$ of the HOXD locus on chromosome 2, promotes the histone $\mathrm{H} 3 \mathrm{~K} 27$ trimethylation and results in transcriptional repression of HOXD locus (Fig. 3C). Therefore, HOTAIR represents an ncRNA that exerts transcriptional repression, at least in part, through recruitment of the chromatin modifying enzyme complex PRC2.

\section{DNA Methylation}

Many protein-coding genes have antisense partners, including tumor suppressor genes (Yu et al. 2008). Misregulation of the associated antisense ncRNAs may subsequently silence the tumor suppressor gene (Fig. 4A), leading to oncogenesis (Yu et al. 2008).

\section{P15AS}

A long ( $200 \mathrm{bp}$ ) antisense ncRNA, P15AS, was identified from $P 15$ gene. $P 15$ is frequently hypermethylated, thus silenced, in leukaemia (Lubbert 2003). It is well established that small ncRNAs, such as microRNA and piRNA, can mediate DNA methylation in many species (Bao et al.
2004; Matzke et al. 2004; Ronemus and Martienssen 2005). The opposite expression patterns between P15AS and $P 15$ raise the possibility that $P 15 A S$ may trigger epigenetic silencing of the $p 15$ genes in cancer cell lines. Indeed, the activity of the $P 15$ promoter could not be reactivated by removal of p15AS (Yu et al. 2008). In the presence of exogenous $p 15 A S$, the $p 15$ promoter showed a marked increase in dimethylation of $\mathrm{H} 3 \mathrm{~K} 9$ and a decrease in dimethylation of H3K4 in human cancer cell lines and mouse embryonic stem cells (Yu et al. 2008). DNA hypermethylation was induced by $p 15 A S$ when embryonic stem cells were differentiated into embryoid bodies (Yu, Gius et al. 2008). Antisense transcript-mediated silencing could be a general mechanism for the silencing of many other tumor suppressor genes in cancer, many of which have long antisense transcripts (Fig. 4A).

\section{Khps1}

Khps1 is an antisense, long ncRNAs generated from the regulatory region (T-DMR) of the sense transcript Sphkl (Imamura et al. 2004). When overexpressed, Khps1 leads to $\mathrm{CpG}$ demethylation and simultaneous non-CG methylation in the T-DMR (Imamura et al. 2004), the methylation status of which correlates with the regulation of Sphkl expression (Imamura et al. 2001). This RNA-induced CG demethylation and non-CG methylation suggests an intriguing and important connection between ncRNAs and epigenetic regulation (Imamura et al. 2004).

\section{General Transcription Factors and RNA pol II Loading}

It is known that RNA has the ability to regulate bacterial RNA polymerase activity (Wassarman and Storz 2000). There are now quite a few cases in which long ncRNAs have been reported to promote or repress transcription by binding to mammalian RNA pol II and modulating the latter's loading on the promoters of regulated genes (Fig. 4B).

\section{Alu RNA}

Massive ncRNAs have been found to be transcribed from the SINEs retrotransposon elements, including Alu repeats in human cells and SINE B1 and SINE B2 in mouse cells (Maraia et al. 1993; Kramerov and Vassetzky 2005). These ncRNAs have been suggested to be involved in gene regulation through roles in transcription, mRNA editing, or even miRNA regulation (Reviewed in Hasler and Strub 2006; Hasler et al. 2007). Alu RNA and SINE B2 RNA have been shown to repress mRNA transcription by preventing RNA pol II loading during heat shock (Allen et al. 2004; Espinoza et al. 2004; Espinoza et al. 2007; Mariner et al. 2008; Yakovchuk et al. 2009). Both SINE B2 and Alu RNA 
X. Wang et al.

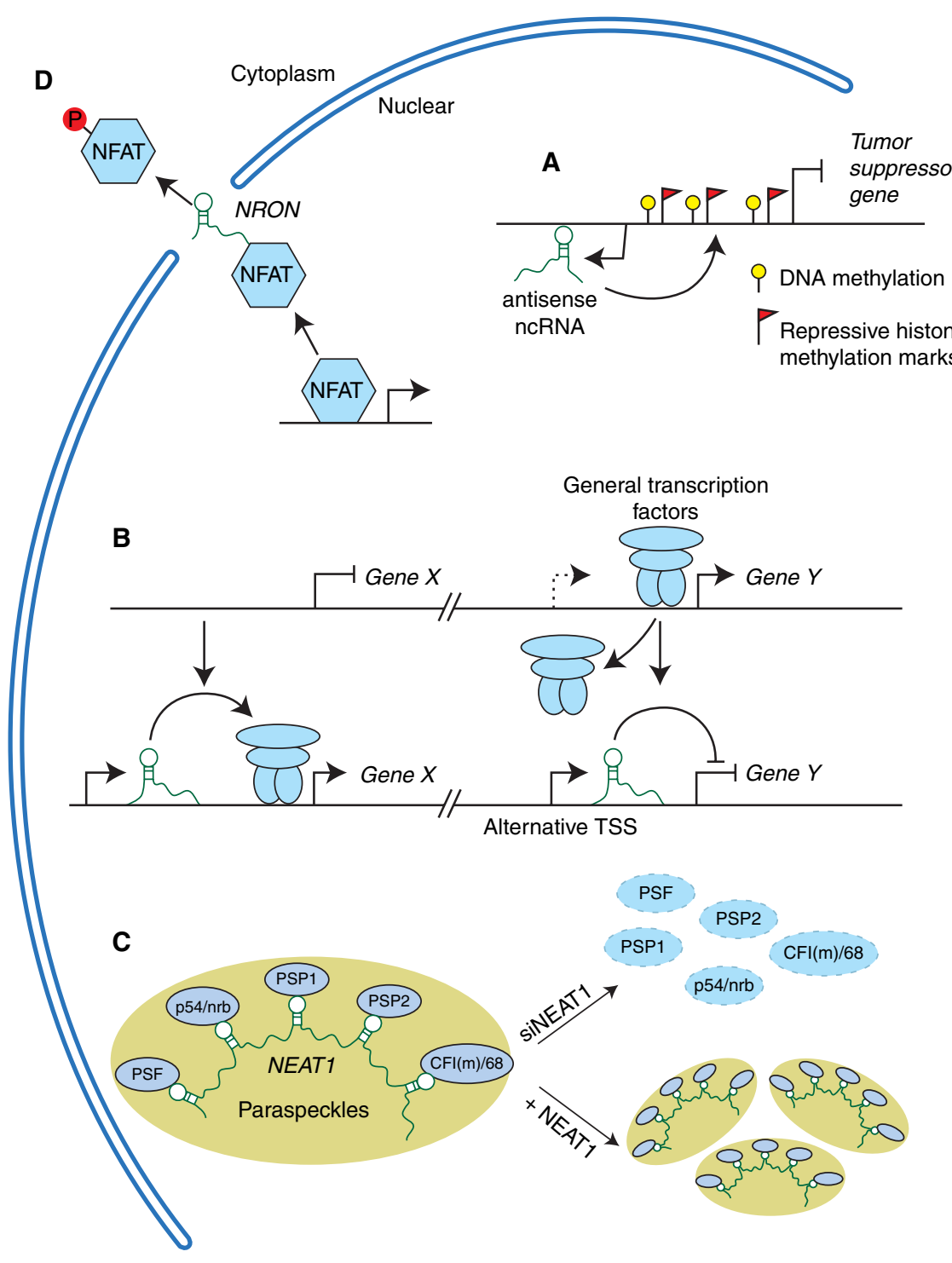

Figure 4. NcRNAs act as transcription regulators via diverse mechanism. (A) Antisense ncRNA from tumor suppressor gene (TSG) induces DNA and repressive histone methylation on the promoter of TSG. $(B)$ NcRNA generated from an alternative transcription start site (TSS) plays either a repressive or activating role by modulating the recruitment of general transcription factors on the promoter of its adjacent gene. (C) NcRNA NEAT1 is specifically expressed in paraspeckles and colocalized with paraspeckle markers (PSF, p54/nrb, PSP1, PSP2 and CFI(m)/68). Knockdown of NEAT1 by specific siRNA disrupts paraspeckles, whereas overexpression of NEAT1 increases the number of paraspeckles. (D) NcRNA NRON prevents nuclear localization of the transcription factor NFAT.

could directly bind to RNA pol II with a high affinity (Allen et al. 2004; Espinoza et al. 2004; Mariner et al. 2008). Surprisingly, Alu RNA contains modular domains, a hallmark of protein regulators of RNA pol II transcription (Mariner et al. 2008). The modular domain of Alu RNA can be fused to a RNA pol II-binding SINE B1 RNA to mediate transcription repression, in a manner similar to trans-acting protein transcription factors (Mariner et al. 2008). Because SINE B2 RNA is able to block the association of RNA pol II as a DNA/RNA hybrid, it was proposed that the modular repression domains in Alu RNA target the DNA-binding channel of RNA pol II and thus prevent the polymerase from forming proper contacts with promoter DNA (Mariner et al. 2008). Indeed, this hypothesis was supported by a series of biochemical assays (Yakovchuk et al. 2009). Alu RNA and SINE B2 RNA apparently prevented the closed complexes between RNA pol II and the promoter DNA, despite the fact that RNA pol II remains associated 
with the promoter DNA. This effect is reversible in the presence of RNase I, but only so before the formation of the closed complex, suggesting these two ncRNAs block the re-engagement of RNA pol II on the promoter DNA (Yakovchuk et al. 2009). Together, these data suggest that ncRNAs derived from SINE elements function as transrepressors of gene expression.

\section{Fbp1+ ncRNA}

In the fission yeast $S$. pombe, the expression of $f b p 1+$ is induced by glucose starvation (Hirota et al. 2008). Glucose starvation also induces at least three large ( $\sim$ several $\mathrm{kb})$ and rare sense-stranded ncRNA transcripts before induction of the $f b p 1+$ transcript. The transcription start sites (TSSs) for these ncRNAs are located at $\sim-1.3 \mathrm{~kb}$ to -530 bp from the ATG. During the glucose starvation, the RNA pol II binding sites shift from the $5^{\prime}$ to $3^{\prime}$ region in the $f b p 1+$ promoter (from ncRNA to $f b p 1+$ transcript), paralleling a corresponding alteration of chromatin structure determined by MNase digestion. Disruption of the ncRNA transcripts by inserting a terminator between the ncRNA transcripts and the TATA box resulted in short and premature ncRNA products, failed RNA pol II recruitment, and chromatin remodeling in the downstream region of the terminator, and eliminated $f b p 1+$ induction in the absence of glucose (Hirota et al. 2008). These results suggest that the RNA pol II-mediated ncRNA transcripts across the $f b p 1+$ promoter increased access to the RNA polymerase and transcriptional activators through progressive opening of chromatin structure (Fig. 4B). Although they affect the activity of general transcription factors and/or RNA pol II, these long ncRNAs regulate gene transcription in a gene-specific manner. It will therefore be of interest to determine whether additional cis acting ncNRAs are involved in these functions.

\section{Transcription Interference}

Alternative TSSs have been found on $>80 \%$ of the tested genes by the Encyclopedia of DNA Elements (ENCODE) project (Trinklein et al. 2003; Carninci et al. 2005; Cooper et al. 2006; Birney et al. 2007; Kawaji et al. 2009). These newly identified TSSs are located at $5^{\prime}$ distal or internal to the annotated gene boundary. Long ncRNA transcripts generated from the alternative TSS may affect the transcription of the adjacent mRNA genes by interference with the loading of the general transcriptional factor, such as TBP (Fig. $4 \mathrm{~B})$. The examples of this mechanism are a long ncRNA generated from an upstream minor promoter that inhibits the DHFR gene encoding dihydrofolate in human (Martianov et al. 2007) and a long ncRNA, SRG1, transcribed from the upstream alternative TSS of the SER3 gene in S. cerevisiae (Martens et al. 2004; Martens et al. 2005).

\section{Regulating the Activity of Transcriptional Factors}

By screening a short hairpin RNA library against 512 evolutionarily conserved putative ncRNAs, an ncRNA - NRON (noncoding repressor of NFAT), was found to repress the nuclear factor of activated T cells (NFAT) family (Willingham et al. 2005). NRON has three splicing variants, with size ranging from $0.8 \mathrm{~kb}$ to $3.7 \mathrm{~kb}$. NRON showed tissuespecific expression and it was particularly enriched in lymphoid tissues. Eleven proteins were found to bind to $N R O N$, including importin- $\beta$ and factors directly mediating the nuclear-cytoplasmic transport of cargoes such as NFAT, suggesting that NRON may act as a modulator of NFAT nuclear trafficking (Fig. 4D). This was supported by the evidence that the level of nuclear NFAT was greatly elevated in the presence of NRON shRNA (Willingham et al. 2005). It is unknown if the role of $N R O N$ is to repress nuclear import or to promote the nuclear export of NFAT.

The mechanisms of long ncRNA regulating transcription are diverse, many of which are not included in above discussion. For example, a newly identified ncRNA, HSR1, has been shown to be involved in regulating the activity of the heat shock transcriptional factor 1 (HSF1) (Shamovsky et al. 2006). Because HSR1 was coimmunoprecipited from HSF1-eEF1A complex, the interaction of HSR1 and eEF1A was suggested to be required for the activation of HSF1 during heat shock.

\section{BIOLOGICAL ROLES OF LONG NCRNAS}

Although still unresolved, the idea that many or even a majority of the ncRNA transcripts are functional has been suggested by the fact that the percentage of the ncRNAs transcribed in the genome is proportional to the complexity of the organism (Taft et al. 2007), and it has received initial experimental support.

\section{Roles of Promoter-Associated ncRNAs}

Transcriptome maps in the entire nonrepetitive portion of the human genome revealed many long ncRNAs (and short ncRNAs) around promoter regions (Kapranov et al. 2007). The number of identified promoter-associated ncRNAs continues to grow in human (Calin et al. 2007; Guenther et al. 2007; Kapranov et al. 2007) as well as other species (Davis and Ares 2006; Guenther et al. 2007). Many of these transcripts are under precise control of diverse signals. Another class of less stable ncRNAs, promoter upstream transcripts, was revealed after siRNA deletion 
of hRrp40, a core component of the human $3^{\prime}$ to $5^{\prime}$ exoribonucleolytic exosome, which is one of the major RNA degradation complexes (Preker et al. 2008). These transcripts are reminiscent of the cryptic unstable transcripts in S. cerevisiae (Wyers et al. 2005; Neil et al. 2009; Xu et al. 2009), which are located $0.5-2.5 \mathrm{~kb}$ upstream of active TSSs and require the downstream promoters. Promoter upstream transcripts partially overlap with promoterassociated ncRNAs, but lack their own known promoters. Both promoter-associated and upstream ncRNAs can be bidirectionally transcribed. These ncRNAs are postulated to have regulatory functions, as suggested by a few ncRNAs that are experimentally supported to regulate transcription of downstream genes, e.g., CCND1ncRNA (Wang et al. 2008), Khpsla (Imamura et al. 2004), and DHFR ncRNA (Martianov et al. 2007), although some events have been suggested to reflect "occlusion" rather than via recruiting RNA-binding proteins or controlling CpG demethylation (Imamura et al. 2004); however, those events are likely to be mechanistically linked. An alternative, nonexclusive function of these long ncRNAs around or upstream of active promoters is to alter chromatin structure through their own transcription.

\section{Roles of ncRNAs as "Transcriptional" Boundary Markers}

Almost half of the human protein-coding genes have been suggested to be marked by both promoter- and 3'-associated short ncRNAs (Kapranov et al. 2007; Borel et al. 2008). That $40 \%$ of the small ncRNAs could be processed from long ncRNAs as indicated by the genome-wide, high resolution tiling arrays (Kapranov et al. 2007) raises the possibility that at least a portion of the short ncRNAs represent processed products of the long ncRNAs, thus serving as markers of boundaries of mRNA transcription units. In addition, they may function in stabilizing "transcriptional" boundaries (Kapranov et al. 2007), conceptually analogous to the proposed network for boundary elements, such as CTCF (Phillips and Corces 2009).

\section{Roles of ncRNAs as Sensors of Signals}

In concert with their ability to recruit specific complexes, long ncRNAs appear to function as sensors of developmental signals and other signaling pathways, such as genotoxic stress. As an example, we have reported that CCND1 ncRNAs, generated in the regulatory region of the $C C N D 1$, sense the genotoxic stress signal and up-regulate, followed by in cis recruiting TLS, which leads to its changing conformation to be able to bind and inhibit CBP/p300 and results in CCND1 mRNA repression (Wang et al. 2008).
Although we will not discuss in detail the function of the long ncRNAs in dosage compensation and imprinting in this review, we would like to point out a $1.6-\mathrm{kb}$ long ncRNA (RepA) within another long ncRNA, Xist, functions as a developmental signal sensor, at onset of $\mathrm{X}$-inactivation when the antisense ncRNA Tsix is down-regulated, and recruits the PRC2 complex to Xist, which leads to the initiation and spreading of X-inactivation (Zhao et al. 2008). Likewise, preferentially expressed in posterior and distal sites, HOTAIR in the HOXC cluster targets PRC2 to distant loci in HOXD and regresses its expression in trans, representing an example of long ncRNAs sensing developmental signals that control anterior-posterior axis (Rinn et al. 2007).

\section{Potential Roles in Structural Integrity of Cellular Organellels and Architecture}

Analogous to the role of rRNAs in ribosome assembly, long ncRNAs can exert functional roles in specific nuclear organelle assembly, exemplified by the actions of the long ncRNA NEAT1 (MEN $\epsilon$ ), which is functionally essential for structural integrity of nuclear paraspeckles (Fox et al., 2002: Clemson et al. 2009; Sasaki et al. 2009; Sunwoo et al. 2009). NEAT1 (MENE) and NEAT2 are the two (out of three) large, polyadenylated, nuclear enriched ncRNAs identified in two human female cell lines using Affymetrix U133A and U133B expression arrays (Hutchinson et al. 2007). Both genes are located on human chromosome 11 , and have no significant homology to each other. However, they both are highly conserved within the mammalian lineage, suggesting a role specific for mammals during evolution. NEAT2 is colocalized with SC-35+ nuclear speckles/inter-chromatin granules, whereas NEAT1 $(M E N \epsilon)$ is localized predominantly to domains adjacent to nuclear speckles-paraspeckles (Fox et al. 2002; Clemson et al. 2009; Sasaki et al. 2009; Sunwoo et al. 2009). Paraspeckles are marked by paraspeckle-associated proteins-PSP1, PSP2, PSF/PSFQ, and $554 / \mathrm{nrb}$, and possibly $\mathrm{CFI}(\mathrm{m}) / 68$, whose functions have been suggested in transcription, pre-mRNA splicing and nuclear retention of RNA (Fox et al. 2002; Dettwiler et al. 2004; Fox et al. 2005). Knock-down of NEAT1 (MENe), but not NEAT2, specifically eradicated paraspeckles in many cell lines including 293, HeLa, HT-1080, and Tig1, suggesting that NEAT1 (MEN $\epsilon$ ) RNA is required for paraspeckle formation (Fig. 4C). On the other hand, overexpression of NEAT1 $(M E N \epsilon)$ induced more paraspeckle staining (Fig. 4C). In addition, the flexibility of RNA to accommodate a series of complexes and to extend across large physical distances, suggests the potential to play key roles in regulation of nuclear architecture. 


\section{CONCLUSIONS AND PERSPECTIVES}

Together, the cumulative data suggest that ncRNAs exert important regulatory functions in the control of transcriptional programs (Fig. 1). Because of the large number of long ncRNAs, and their functions in "nucleating" molecules for combinatorial complex assembly, the resultant ncRNA-protein interactions are likely to serve as "sensors" for a variety of developmental and signaling pathways, nuclear receptor ligands, and genotoxic-stress. The presence of ss ncRNA versus regions of ds ncRNAs is likely to be dynamically regulated in the environment of the cell. This relationship may dictate the alternative recruitment of "corepressors," "coactivators," and DNA-modifying complexes. Thus it is tempting to postulate that the ncRNAs might themselves serve as the critical arbiters of local DNA methylation patterns and even as key arbiters in establishing regions of "epigenetic" memory. Conversely, it is likely that alterations in strandedness/transcriptional length/splicing of ncRNAs functionally modulate their actions. An additional consideration in the actions of long ncRNAs relates to the architecture of most RNAbinding proteins, which contain multiple RNA-binding domains that may recognize distinct "targets." This implies that many RNA-binding proteins might, as a consequence, show distinct "allosterically-dictated" conformations based on the specific RNA sequences they bind that might regulate interactions with other proteins required for distinct functions-for example at promoters versus during transcriptional elongation/splicing. Given that RNAbinding proteins constitute the largest "transcriptional" regulatory family in the genome (Burd and Dreyfuss 1994; Lunde et al. 2007), ncRNA/RNA-binding proteinbased strategy to integrate transcriptional programs is very likely a general rule in the transcriptional as well as RNA processing regulation. Considering the broad expression of ncRNAs, and the ambiguity of any sequence specificity of the reported ncRNAs acting in trans, it is even possible that they are recruited by cis-acting ncRNAs. Together, the ncRNA sensor code appears to be a robust and critical strategy underlying a wide variety of gene regulatory programs and we are certain to see an explosive increment of knowledge and insights into this area in the coming months.

\section{ACKNOWLEDGMENTS}

We thank J. Hightower and D. Benson for assistance figure preparation. We thank X. Su for useful discussion. Work cited from our laboratories was supported by National Institutes of Health (NIH) grants to CKG and to MGR. XW is supported by NIH grant 5T32DK007044-28. XS is supported by the Irvington Institute Fellowship Program of the Cancer Research Institute. MGR is an HHMI investigator. X. Wang and X. Song contributed equally to this work.

\section{REFERENCES}

Allen TA, Von Kaenel S, Goodrich JA, Kugel JF. 2004. The SINE-encoded mouse B2 RNA represses mRNA transcription in response to heat shock. Nat Structural Mol Biol 11: 816-821.

Amaral PP, Mattick JS. 2008. Noncoding RNA in development. Mamm Genome 19: 454-492.

Ambros V. 2001. microRNAs: tiny regulators with great potential. Cell 107: $823-826$.

Aravin A, Gaidatzis D, Pfeffer S, Lagos-Quintana M, Landgraf P, Iovino $\mathrm{N}$, Morris $\mathrm{P}$, Brownstein MJ, Kuramochi-Miyagawa $\mathrm{S}$, Nakano T, et al. 2006. A novel class of small RNAs bind to MILI protein in mouse testes. Nature 442: 203-207.

Bao N, Lye KW, Barton MK. 2004. MicroRNA binding sites in Arabidopsis class III HD-ZIP mRNAs are required for methylation of the template chromosome. Develop Cell 7: 653-662.

Batey RT, Rambo RP, Lucast L, Rha B, Doudna JA. 2000. Crystal structure of the ribonucleoprotein core of the signal recognition particle. Science 287: $1232-1239$.

Beisel C, Buness A, Roustan-Espinosa IM, Koch B, Schmitt S, Haas SA, Hild M, Katsuyama T, Paro R. 2007. Comparing active and repressed expression states of genes controlled by the Polycomb/Trithorax group proteins. Proc Nat Acad Sci 104: 16615-16620.

Bernstein E, Allis CD. 2005. RNA meets chromatin. Genes \& Development 19: $1635-1655$.

Bertone P, Stolc V, Royce TE, Rozowsky JS, Urban AE, Zhu X, Rinn JL, Tongprasit W, Samanta M, Weissman S, et al. 2004. Global identification of human transcribed sequences with genome tiling arrays. Science 306: 2242-2246.

Birney E, Stamatoyannopoulos JA, Dutta A, Guigo R, Gingeras TR, Margulies EH, Weng Z, Snyder M, Dermitzakis ET, Thurman RE, et al. 2007. Identification and analysis of functional elements in $1 \%$ of the human genome by the ENCODE pilot project. Nature 447: 799-816.

Bond AM, Vangompel MJ, Sametsky EA, Clark MF, Savage JC, Disterhoft JF, Kohtz JD. 2009. Balanced gene regulation by an embryonic brain ncRNA is critical for adult hippocampal GABA circuitry. Nat Neurosci 12: $1020-1027$.

Borel C, Gagnebin M, Gehrig C, Kriventseva EV, Zdobnov EM, Antonarakis SE. 2008. Mapping of small RNAs in the human ENCODE regions. Am J Human Gen 82: 971-981.

Brown CJ, Hendrich BD, Rupert JL, Lafreniere RG, Xing Y, Lawrence J, Willard HF. 1992. The human XIST gene: Analysis of a $17 \mathrm{~kb}$ inactive $\mathrm{X}$-specific RNA that contains conserved repeats and is highly localized within the nucleus. Cell 71: 527-542.

Bruce AW, Lopez-Contreras AJ, Flicek P, Down TA, Dhami P, Dillon SC, Koch CM, Langford CF, Dunham I, Andrews RM, et al. 2009. Functional diversity for REST (NRSF) is defined by in vivo binding affinity hierarchies at the DNA sequence level. Genome Research 19: 994-1005.

Burd CG, Dreyfuss G. 1994. Conserved structures and diversity of functions of RNA-binding proteins. Science 265: 615-621.

Calin GA, Liu CG, Ferracin M, Hyslop T, Spizzo R, Sevignani C, Fabbri M, Cimmino A, Lee EJ, Wojcik SE, et al. 2007. Ultraconserved regions encoding ncRNAs are altered in human leukemias and carcinomas. Cancer Cell 12: 215-229.

Caretti G, Schiltz RL, Dilworth FJ, Di Padova M, Zhao P, Ogryzko V, Fuller- Pace FV, Hoffman EP, Tapscott SJ, Sartorelli V. 2006. The RNA helicases p68/p72 and the noncoding RNA SRA are coregulators of MyoD and skeletal muscle differentiation. Develop Cell 11: 547-560.

Carninci P, Kasukawa T, Katayama S, Gough J, Frith MC, Maeda N, Oyama R, Ravasi T, Lenhard B, Wells C, et al. 2005. The transcriptional landscape of the mammalian genome. Science 309: 1559-1563. 
Carninci P, Sandelin A, Lenhard B, Katayama S, Shimokawa K, Ponjavic J, Semple CA, Taylor MS, Engstrom PG, Frith MC, et al. 2006. Genomewide analysis of mammalian promoter architecture and evolution. Nat Gen 38: 626-635.

Cawley S, Bekiranov S, Ng HH, Kapranov P, Sekinger EA, Kampa D, Piccolboni A, Sementchenko V, Cheng J, Williams AJ, et al. 2004. Unbiased mapping of transcription factor binding sites along human chromosomes 21 and 22 points to widespread regulation of noncoding RNAs. Cell 116: 499-509.

Chen X, Xu H, Yuan P, Fang F, Huss M, Vega VB, Wong E, Orlov YL, Zhang W, Jiang J, et al. 2008. Integration of external signaling pathways with the core transcriptional network in embryonic stem cells. Cell 133: $1106-1117$

Cheng J, Kapranov P, Drenkow J, Dike S, Brubaker S, Patel S, Long J, Stern D, Tammana H, Helt G, et al. 2005. Transcriptional maps of 10 human chromosomes at 5-nucleotide resolution. Science 308: 1149-1154.

Clemson CM, Hutchinson JN, Sara SA, Ensminger AW, Fox AH, Chess A, Lawrence JB. 2009. An architectural role for a nuclear noncoding RNA: NEAT1 RNA is essential for the structure of paraspeckles. Mol Cell 33: 717-726.

Cooper SJ, Trinklein ND, Anton ED, Nguyen L, Myers RM. 2006. Comprehensive analysis of transcriptional promoter structure and function in $1 \%$ of the human genome. Gen Res 16: $1-10$.

Costa FF. 2007. Non-coding RNAs: lost in translation? Gene 386: 1-10.

Davis CA, Ares MJr., 2006. Accumulation of unstable promoter-associated transcripts upon loss of the nuclear exosome subunit Rrp6p in Saccharomyces cerevisiae. Proc Nat Acad Sci 103: 3262-3267.

de Napoles M, Mermoud JE, Wakao R, Tang YA, Endoh M, Appanah R, Nesterova TB, Silva J, Otte AP, Vidal M, et al. 2004. Polycomb group proteins Ring1A/B link ubiquitylation of histone $\mathrm{H} 2 \mathrm{~A}$ to heritable gene silencing and X inactivation. Develop Cell 7: 663-676.

Deblois G, Giguere V. 2003. Ligand-independent coactivation of ER $\alpha$ AF-1 by steroid receptor RNA activator (SRA) via MAPK activation. J Steroid Biochem Mol Biol 85: 123-131.

Dettwiler S, Aringhieri C, Cardinale S, Keller W, Barabino SM. 2004. Distinct sequence motifs within the $68-\mathrm{kDa}$ subunit of cleavage factor Im mediate RNA binding, protein-protein interactions, subcellular localization. J Biol Chem 279: 35788-35797.

Dieci G, Fiorino G, Castelnuovo M, Teichmann M, Pagano A. 2007. The expanding RNA polymerase III transcriptome. Trends Genet 23: 614622.

Dinger ME, Amaral PP, Mercer TR, Pang KC, Bruce SJ, Gardiner BB, Askarian-Amiri ME, Ru K, Solda G, Simons C, et al. 2008. Long noncoding RNAs in mouse embryonic stem cell pluripotency and differentiation. Gen Res 18: 1433-1445.

Espinoza CA, Allen TA, Hieb AR, Kugel JF, Goodrich JA. 2004. B2 RNA binds directly to RNA polymerase II to repress transcript synthesis. Nat Structural Mol Biol 11: 822-829.

Espinoza CA, Goodrich JA, Kugel JF. 2007. Characterization of the structure, function, mechanism of B2 RNA, an ncRNA repressor of RNA polymerase II transcription. RNA 13: 583-596.

Feng J, Bi C, Clark BS, Mady R, Shah P, Kohtz JD. 2006. The Evf-2 noncoding RNA is transcribed from the Dlx-5/6 ultraconserved region and functions as a Dlx-2 transcriptional coactivator. Genes Develop 20: $1470-1484$.

Fox AH, Bond CS, Lamond AI. 2005. P54nrb forms a heterodimer with PSP1 that localizes to paraspeckles in an RNA-dependent manner. Mol Biol Cell 16: 5304-5315.

Fox AH, Lam YW, Leung AK, Lyon CE, Andersen J, Mann M, Lamond AI. 2002. Paraspeckles: A novel nuclear domain. Curr Biol 12: 13-25.

Ginger MR, Shore AN, Contreras A, Rijnkels M, Miller J, Gonzalez-Rimbau MF, Rosen JM. 2006. A noncoding RNA is a potential marker of cell fate during mammary gland development. Proc Nat Acad Sci 103: $5781-5786$

Girard A, Sachidanandam R, Hannon GJ, Carmell MA. 2006. A germlinespecific class of small RNAs binds mammalian Piwi proteins. Nature 442: 199-202.
Glass CK, Rosenfeld MG. 2000. The coregulator exchange in transcriptional functions of nuclear receptors. Genes Develop 14: 121-141.

Goodrich JA, Kugel JF. 2006. Non-coding-RNA regulators of RNA polymerase II transcription. Nat Rev Mol Cell Biol 7: 612-616.

Grishok A, Mello CC. 2002. RNAi (Nematodes: Caenorhabditis elegans). Adv Gen 46: 339-360.

Grivna ST, Beyret E, Wang Z, Lin H. 2006. A novel class of small RNAs in mouse spermatogenic cells. Genes Develop 20: 1709-1714.

Guenther MG, Levine SS, Boyer LA, Jaenisch R, Young RA. 2007. A chromatin landmark and transcription initiation at most promoters in human cells. Cell 130: 77-88.

Gustincich S, Sandelin A, Plessy C, Katayama S, Simone R, Lazarevic D, Hayashizaki Y, Carninci P. 2006. The complexity of the mammalian transcriptome. J Physiol 575: 321-332.

Guttman M, Amit I, Garber M, French C, Lin MF, Feldser D, Huarte M, Zuk O, Carey BW, Cassady JP, et al. 2009. Chromatin signature reveals over a thousand highly conserved large non-coding RNAs in mammals. Nature 458: 223-227.

Hasler J, Samuelsson T, Strub K. 2007. Useful 'junk': Alu RNAs in the human transcriptome. Cell Mol Life Sci 64: 1793-1800.

Hasler J, Strub K. 2006. Alu elements as regulators of gene expression. Nuc Acids Res 34: 5491-5497.

Hatchell EC, Colley SM, Beveridge DJ, Epis MR, Stuart LM, Giles KM, Redfern AD, Miles LE, Barker A, MacDonald LM, et al. 2006. SLIRP, a small SRA binding protein, is a nuclear receptor corepressor. $\mathrm{Mol}$ Cell 22: 657-668.

Hirota K, Miyoshi T, Kugou K, Hoffman CS, Shibata T, Ohta K. 2008. Stepwise chromatin remodelling by a cascade of transcription initiation of non-coding RNAs. Nature 456: 130-134.

Hutchinson JN, Ensminger AW, Clemson CM, Lynch CR, Lawrence JB, Chess A. 2007. A screen for nuclear transcripts identifies two linked noncoding RNAs associated with SC35 splicing domains. BMC Genomics 8: 39 .

Imamura T, Ohgane J, Ito S, Ogawa T, Hattori N, Tanaka S, Shiota K. 2001. CpG island of rat sphingosine kinase-1 gene: tissue-dependent DNA methylation status and multiple alternative first exons. Genomics 76: $117-125$.

Imamura T, Yamamoto S, Ohgane J, Hattori N, Tanaka S, Shiota K. 2004. Non-coding RNA directed DNA demethylation of Sphk1 CpG island. Biochem Biophys Res Comm 322: 593-600.

Johnson JM, Edwards S, Shoemaker D, Schadt EE. 2005. Dark matter in the genome: evidence of widespread transcription detected by microarray tiling experiments. Trends Genet 21: 93-102.

Johnson R, Teh CH, Jia H, Vanisri RR, Pandey T, Lu ZH, Buckley NJ, Stanton LW, Lipovich L. 2009. Regulation of neural macroRNAs by the transcriptional repressor REST. RNA 15: 85-96.

Kapranov P, Cheng J, Dike S, Nix DA, Duttagupta R, Willingham AT, Stadler PF, Hertel J, Hackermuller J, Hofacker IL, et al. 2007. RNA maps reveal new RNA classes and a possible function for pervasive transcription. Science 316: 1484-1488.

Katayama S, Tomaru Y, Kasukawa T, Waki K, Nakanishi M, Nakamura M, Nishida H, Yap CC, Suzuki M, Kawai J, et al. 2005. Antisense transcription in the mammalian transcriptome. Science 309: 1564-1566.

Kawaji H, Severin J, Lizio M, Waterhouse A, Katayama S, Irvine KM, Hume DA, Forrest AR, Suzuki H, Carninci P, et al. 2009. The FANTOM web resource: from mammalian transcriptional landscape to its dynamic regulation. Gen Biol 10: pR40.

Kawashima H, Takano H, Sugita S, Takahara Y, Sugimura K, Nakatani T. 2003. A novel steroid receptor co-activator protein (SRAP) as an alternative form of steroid receptor RNA-activator gene: Expression in prostate cancer cells and enhancement of androgen receptor activity. Biochem J 369: 163-171.

Khalil AM, Guttman M, Huarte M, Garber M, Raj A, Rivea Morales D, Thomas K, Presser A, Bernstein BE, van Oudenaarden A, et al. 2009. Many human large intergenic noncoding RNAs associate with chromatin-modifying complexes and affect gene expression. Proc Nat Acad Sci 106: 11667-11672. 
Kim TH, Barrera LO, Zheng M, Qu C, Singer MA, Richmond TA, Wu Y, Green RD, Ren B. 2005. A high-resolution map of active promoters in the human genome. Nature 436: 876-880.

Koch F, Jourquin F, Ferrier P, Andrau JC. 2008. Genome-wide RNA polymerase II: Not genes only! Trends in Biochem Sci 33: 265-273.

Kramerov DA, Vassetzky NS. 2005. Short retroposons in eukaryotic genomes. International Review of Cytology 247: 165-221.

Kraner SD, Chong JA, Tsay HJ, Mandel G. 1992. Silencing the type II sodium channel gene: A model for neural-specific gene regulation. Neuron 9: 37-44.

Kurokawa R, Rosenfeld MG, Glass CK. 2009. Transcriptional regulation through noncoding RNAs and epigenetic modifications. RNA Biology 6: $233-236$.

Kuwabara T, Hsieh J, Nakashima K, Taira K, Gage FH. 2004. A small modulatory dsRNA specifies the fate of adult neural stem cells. Cell 116: $779-793$

Lanz RB, McKenna NJ, Onate SA, Albrecht U, Wong J, Tsai SY, Tsai MJ, O’Malley BW. 1999. A steroid receptor coactivator, SRA, functions as an RNA and is present in an SRC-1 complex. Cell 97: 17-27.

Lau NC, Seto AG, Kim J, Kuramochi-Miyagawa S, Nakano T, Bartel DP, Kingston RE. 2006. Characterization of the piRNA complex from rat testes. Science 313: 363-367.

Lee HC, Chang SS, Choudhary S, Aalto AP, Maiti M, Bamford DH, Liu Y. 2009. qiRNA is a new type of small interfering RNA induced by DNA damage. Nature 459: 274-277.

Lee Y, Kim M, Han J, Yeom KH, Lee S, Baek SH, Kim VN. 2004. MicroRNA genes are transcribed by RNA polymerase II. EMBO J 23: 40514060.

Li F, Schiemann AH, Scott MJ. 2008. Incorporation of the noncoding roX RNAs alters the chromatin-binding specificity of the Drosophila MSL1/MSL2 complex. Mol Cell Biol 28: 1252-1264.

Liu WM, Chu WM, Choudary PV, Schmid CW. 1995. Cell stress and translational inhibitors transiently increase the abundance of mammalian SINE transcripts. Nucleic Acids Res 23: 1758-1765.

Louro R, Smirnova AS, Verjovski-Almeida S. 2009. Long intronic noncoding RNA transcription: Expression noise or expression choice? Genomics 93: 291-298.

Lubbert M. 2003. Gene silencing of the p15/INK4B cell-cycle inhibitor by hypermethylation: An early or later epigenetic alteration in myelodysplastic syndromes? Leukemia 17: 1762-1764.

Lunde BM, Moore C, Varani G. 2007. RNA-binding proteins: Modular design for efficient function. Nat Rev Mol Cell Biol 8: 479-490.

Maraia RJ, Driscoll CT, Bilyeu T, Hsu K, Darlington GJ. 1993. Multiple dispersed loci produce small cytoplasmic Alu RNA. Mol Cell Biol 13: $4233-4241$.

Mariner PD, Walters RD, Espinoza CA, Drullinger LF, Wagner SD, Kugel JF, Goodrich JA. 2008. Human Alu RNA is a modular transacting repressor of mRNA transcription during heat shock. Mol Cell 29: 499-509.

Martens JA, Laprade L, Winston F. 2004. Intergenic transcription is required to repress the Saccharomyces cerevisiae SER3 gene. Nature 429: $571-574$

Martens JA, Wu PY, Winston F. 2005. Regulation of an intergenic transcript controls adjacent gene transcription in Saccharomyces cerevisiae. Genes Develop 19: 2695-2704.

Martianov I, Ramadass A, Serra Barros A, Chow N, Akoulitchev A. 2007. Repression of the human dihydrofolate reductase gene by a non-coding interfering transcript. Nature 445: 666-670.

Martone R, Euskirchen G, Bertone P, Hartman S, Royce TE, Luscombe NM, Rinn JL, Nelson FK, Miller P, Gerstein M, et al. 2003. Distribution of NFkappaB- binding sites across human chromosome 22. Proc Nat Acad Sci 100: 12247-12252.

Mattick JS. 1994. Introns: evolution and function. Current Opinion Gen Develop 4: 823-831.

Mattick JS. 2007. A new paradigm for developmental biology. J Exp Biol 210: $1526-1547$.
Mattick JS, Gagen MJ. 2001. The evolution of controlled multitasked gene networks: the role of introns and other noncoding RNAs in the development of complex organisms. Mol Biol Evolution 18: 16111630.

Mattick JS, Makunin IV. 2006. Non-coding RNA. Human Mol Genet 15 Spec No 1, R17-29.

Matzke M, Aufsatz W, Kanno T, Daxinger L, Papp I, Mette MF, Matzke AJ. 2004. Genetic analysis of RNA-mediated transcriptional gene silencing. Biochim Biophys Acta 1677: 129-141.

McKenna NJ, O'Malley BW. 2002. Combinatorial control of gene expression by nuclear receptors and coregulators. Cell 108: 465-474.

Mercer TR, Dinger ME, Mattick JS. 2009. Long non-coding RNAs: Insights into functions. Nat Rev 10: 155-159.

Mercer TR, Dinger ME, Sunkin SM, Mehler MF, Mattick JS. 2008. Specific expression of long noncoding RNAs in the mouse brain. Proc Nat Acad Sci 105: 716-721.

Montgomery MK, Fire A. 1998. Double-stranded RNA as a mediator in sequence-specific genetic silencing and co-suppression. Trends Genet 14: $255-258$.

Mori N, Schoenherr C, Vandenbergh DJ, Anderson DJ. 1992. A common silencer element in the SCG10 and type II Na+ channel genes binds a factor present in nonneuronal cells but not in neuronal cells. Neuron 9 : $45-54$.

Nagano T, Mitchell JA, Sanz LA, Pauler FM, Ferguson-Smith AC, Feil R, Fraser P. 2008. The Air noncoding RNA epigenetically silences transcription by targeting G9a to chromatin. Science 322: 1717-1720.

Neil H, Malabat C, d'Aubenton-Carafa Y, Xu Z, Steinmetz LM, Jacquier A. 2009. Widespread bidirectional promoters are the major source of cryptic transcripts in yeast. Nature 457: 1038-1042.

Nguyen VT, Kiss T, Michels AA, Bensaude O. 2001. 7SK small nuclear RNA binds to and inhibits the activity of CDK9/cyclin T complexes. Nature 414: 322-325.

Nishihara S, Tsuda L, Ogura T. 2003. The canonical Wnt pathway directly regulates NRSF/RESTexpression in chick spinal cord. Biochem Biophys Res Commun 311: 55-63.

Otto SJ, McCorkle SR, Hover J, Conaco C, Han JJ, Impey S, Yochum GS, Dunn JJ, Goodman RH, Mandel G. 2007. A new binding motif for the 7 transcriptional repressor REST uncovers large gene networks devoted to neuronal functions. J Neurosci 27: 6729-6739.

Pasmant E, Laurendeau I, Heron D, Vidaud M, Vidaud D, Bieche I. 2007. Characterization of a germ-line deletion, including the entire INK4/ ARF locus, in a melanoma-neural system tumor family: Identification of ANRIL, an antisense noncoding RNA whose expression coclusters with ARF. Cancer Res 67: 3963-3969.

Phillips JE, Corces VG. 2009. CTCF: Master weaver of the genome. Cell 137: $1194-1211$.

Plath K, Mlynarczyk-Evans S, Nusinow DA, Panning B. 2002. Xist RNA and the mechanism of X chromosome inactivation. Ann Rev Gen 36: 233-278.

Ponting CP, Oliver PL, Reik W. 2009. Evolution and functions of long noncoding RNAs. Cell 136: 629-641.

Preker P, Nielsen J, Kammler S, Lykke-Andersen S, Christensen MS, Mapendano CK, Schierup MH, Jensen TH. 2008. RNA exosome depletion reveals transcription upstream of active human promoters. Science 322: $1851-1854$.

Rinn JL, Kertesz M, Wang JK, Squazzo SL, Xu X, Brugmann SA, Goodnough LH, Helms JA, Farnham PJ, Segal E, et al. 2007. Functional demarcation of active and silent chromatin domains in human HOX loci by noncoding RNAs. Cell 129: 1311-1323.

Ronemus M, Martienssen R. 2005. RNA interference: methylation mystery. Nature 433: 472-473.

Rosenfeld MG, Glass CK. 2001. Coregulator codes of transcriptional regulation by nuclear receptors. J Biol Chem 276: 36865-36868.

Rosenfeld MG, Lunyak VV, Glass CK. 2006. Sensors and signals: A coactivator/corepressor/epigenetic code for integrating signal-dependent programs of transcriptional response. Genes Develop 20: 1405-1428. 
X. Wang et al.

Sanchez-Elsner T, Gou D, Kremmer E, Sauer F. 2006. Noncoding RNAs of trithorax response elements recruit Drosophila Ash1 to Ultrabithorax. Science 311: 1118-1123.

Sasaki YT, Ideue T, Sano M, Mituyama T, Hirose T. 2009. MENepsilon/ $\beta$ noncoding RNAs are essential for structural integrity of nuclear paraspeckles. Proc Nat Acad Sci 106: 2525-2530.

Schoeftner S, Sengupta AK, Kubicek S, Mechtler K, Spahn L, Koseki H, Jenuwein T, Wutz A. 2006. Recruitment of PRC1 function at the initiation of X inactivation independent of PRC2 and silencing. EMBO J 25: $3110-3122$.

Schuettengruber B, Chourrout D, Vervoort M, Leblanc B, Cavalli G. 2007. Genome regulation by polycomb and trithorax proteins. Cell 128: $735-745$.

Scott MJ, Li F. 2008. How do ncRNAs guide chromatin-modifying complexes to specific locations within the nucleus? RNA Biol 5: 13-16.

Shamovsky I, Ivannikov M, Kandel ES, Gershon D, Nudler E. 2006. RNAmediated response to heat shock in mammalian cells. Nature 440: $556-560$

Shi Y, Downes M, Xie W, Kao HY, Ordentlich P, Tsai CC, Hon M, Evans RM. 2001. Sharp, an inducible cofactor that integrates nuclear receptor repression and activation. Genes Develop 15: 1140-1151.

Shi YJ, Matson C, Lan F, Iwase S, Baba T, Shi Y. 2005. Regulation of LSD1 histone demethylase activity by its associated factors. Mol Cell 19: 857-864.

Shilatifard A. 2008. Molecular implementation and physiological roles for histone $\mathrm{H} 3$ lysine 4 (H3K4) methylation. Current Opinion Cell Biol 20: 341-348.

St Laurent G, 3rd, Wahlestedt C. 2007. Noncoding RNAs: couplers of analog and digital information in nervous system function? Trends Neurosci 30: 612-621.

Storz G. 2002. An expanding universe of noncoding RNAs. Science 296: $1260-1263$.

Sunwoo H, Dinger ME, Wilusz JE, Amaral PP, Mattick JS, Spector DL. 2009. MEN epsilon/ $\beta$ nuclear-retained non-coding RNAs are upregulated upon muscle differentiation and are essential components of paraspeckles. Gen Res 19: 347-359.

Taft RJ, Pheasant M, Mattick JS. 2007. The relationship between nonproteincoding DNA and eukaryotic complexity. Bioessays 29: 288299.

Trinklein ND, Aldred SJ, Saldanha AJ, Myers RM. 2003. Identification and functional analysis of human transcriptional promoters. Gen Res 13: 308-312.

Umlauf D, Fraser P, Nagano T. 2008. The role of long non-coding RNAs in chromatin structure and gene regulation: Variations on a theme. Biol Chem 389: 323-331.

Vagin VV, Sigova A, Li C, Seitz H, Gvozdev V, Zamore PD. 2006. A distinct small RNA pathway silences selfish genetic elements in the germline. Science 313: 320-324.

Walter P, Blobel G. 1982. Signal recognition particle contains a 7S RNA essential for protein translocation across the endoplasmic reticulum. Nature 299: 691-698.

Wang P, Yin S, Zhang Z, Xin D, Hu L, Kong X, Hurst LD. (2008b). Evidence for common short natural trans sense-antisense pairing between transcripts from protein coding genes. Gen Biol 9: R169.

Wang X, Arai S, Song X, Reichart D, Du K, Pascual G, Tempst P, Rosenfeld MG, Glass CK, Kurokawa R. (2008a). Induced ncRNAs allosterically modify RNA-binding proteins in cis to inhibit transcription. Nature 454: $126-130$
Wassarman KM, Storz G. 2000. 6S RNA regulates E.coli RNA polymerase activity. Cell 101: 613-623.

Watanabe T, Takeda A, Tsukiyama T, Mise K, Okuno T, Sasaki H, Minami N, Imai H. 2006. Identification and characterization of two novel classes of small RNAs in the mouse germline: Retrotransposonderived siRNAs in oocytes and germline small RNAs in testes. Genes Develop 20: 1732-1743.

Wellik DM. 2009. Hox genes and vertebrate axial pattern. Current Topics Develop Biol 88: 257-278.

Wickiser JK, Winkler WC, Breaker RR, Crothers DM. 2005. The speed of RNA transcription and metabolite binding kinetics operate an FMN riboswitch. Mol Cell 18: 49-60.

Willingham AT, Gingeras TR. 2006. TUF love for “junk” DNA. Cell 125: $1215-1220$

Willingham AT, Orth AP, Batalov S, Peters EC, Wen BG, Aza-Blanc P, Hogenesch JB, Schultz PG. 2005. A strategy for probing the function of noncoding RNAs finds a repressor of NFAT. Science 309: 1570-1573.

Wilusz JE, Sunwoo H, Spector DL. 2009. Long noncoding RNAs: functional surprises from the RNA world. Genes Develop 23: 1494-1504.

Wu Q, Kim YC, Lu J, Xuan Z, Chen J, Zheng Y, Zhou T, Zhang MQ, Wu CI, Wang SM. 2008. Poly A- transcripts expressed in HeLa cells. PloS one 3: e2803.

Wyers F, Rougemaille M, Badis G, Rousselle JC, Dufour ME, Boulay J, Regnault B, Devaux F, Namane A, Seraphin B, et al. 2005. Cryptic pol II transcripts are degraded by a nuclear quality control pathway involving a new poly(A) polymerase. Cell 121: 725-737.

Xu B, Koenig RJ. 2004. An RNA-binding domain in the thyroid hormone receptor enhances transcriptional activation. J Biol Chem 279: 3305133056.

Xu B, Koenig RJ. 2005. Regulation of thyroid hormone receptor $\alpha 2$ RNA binding and subcellular localization by phosphorylation. Mol Cell Endocrinology 245: 147-157.

Xu Z, Wei W, Gagneur J, Perocchi F, Clauder-Munster S, Camblong J, Guffanti E, Stutz F, Huber W, Steinmetz LM. 2009. Bidirectional promoters generate pervasive transcription in yeast. Nature 457: $1033-$ 1037.

Yakovchuk P, Goodrich JA, Kugel JF. 2009. B2 RNA and Alu RNA repress transcription by disrupting contacts between RNA polymerase II and promoter DNA within assembled complexes. Proc Nat Acad Sci 106: $5569-5574$

Yang Z, Zhu Q, Luo K, Zhou Q. 2001. The 7SK small nuclear RNA inhibits the CDK9/cyclin T1 kinase to control transcription. Nature 414: 317-322.

Yelin R, Dahary D, Sorek R, Levanon EY, Goldstein O, Shoshan A, Diber A, Biton S, Tamir Y, Khosravi R, et al. 2003. Widespread occurrence of antisense transcription in the human genome. Nat Biotechnol 21: 379-386.

Yu W, Gius D, Onyango P, Muldoon-Jacobs K, Karp J, Feinberg AP, Cui H. 2008. Epigenetic silencing of tumour suppressor gene p15 by its antisense RNA. Nature 451: 202-206.

Zhao J, Sun BK, Erwin JA, Song JJ, Lee JT. 2008. Polycomb proteins targeted by a short repeat RNA to the mouse X chromosome. Science 322: $750-756$.

Zhao X, Patton JR, Davis SL, Florence B, Ames SJ, Spanjaard RA. 2004. Regulation of nuclear receptor activity by a pseudouridine synthase through posttranscriptional modification of steroid receptor RNA activator. Mol Cell 15: 549-558. 


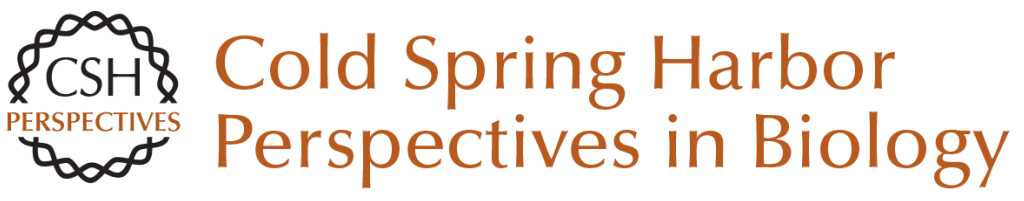

\section{The Long Arm of Long Noncoding RNAs: Roles as Sensors Regulating Gene Transcriptional Programs}

Xiangting Wang, Xiaoyuan Song, Christopher K. Glass and Michael G. Rosenfeld

Cold Spring Harb Perspect Biol 2011; doi: 10.1101/cshperspect.a003756 originally published online June 23, 2010

\section{Subject Collection RNA Worlds}

Alternate RNA Structures

Marie Teng-Pei Wu and Victoria D'Souza

Approaches for Understanding the Mechanisms of Long Noncoding RNA Regulation of Gene

Expression

Patrick McDonel and Mitchell Guttman

Principles and Practices of Hybridization Capture

Experiments to Study Long Noncoding RNAs That

Act on Chromatin

Matthew D. Simon and Martin Machyna

Linking RNA Sequence, Structure, and Function on Massively Parallel High-Throughput

Sequencers

Sarah K. Denny and William J. Greenleaf

Extensions, Extra Factors, and Extreme

Complexity: Ribosomal Structures Provide

Insights into Eukaryotic Translation

Melanie Weisser and Nenad Ban

Nascent RNA and the Coordination of Splicing

with Transcription

Karla M. Neugebauer
Structural Biology of Telomerase

Yaqiang Wang, Lukas Susac and Juli Feigon

Structural Insights into Nuclear pre-mRNA

Splicing in Higher Eukaryotes

Berthold Kastner, Cindy L. Will, Holger Stark, et al.

What Are 3' UTRs Doing?

Christine Mayr

Single-Molecule Analysis of Reverse

Transcriptase Enzymes

Linnea I. Jansson and Michael D. Stone

CRISPR Tools for Systematic Studies of RNA

Regulation

Jesse Engreitz, Omar Abudayyeh, Jonathan

Gootenberg, et al.

Relating Structure and Dynamics in RNA Biology Kevin P. Larsen, Junhong Choi, Arjun Prabhakar, et al.

For additional articles in this collection, see http://cshperspectives.cshlp.org/cgi/collection/

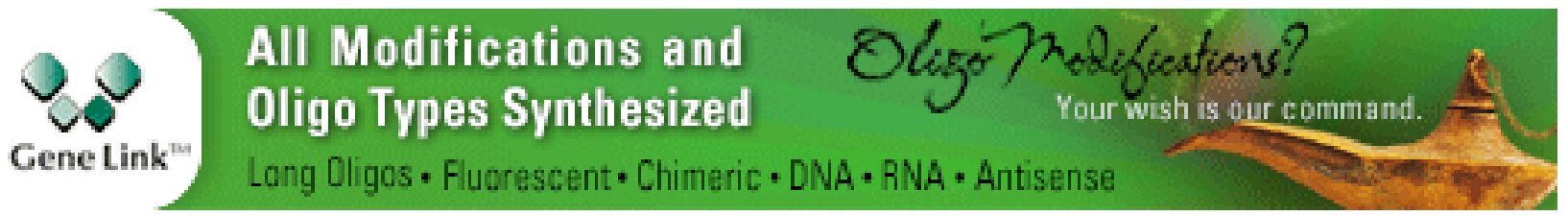

Copyright (C 2011 Cold Spring Harbor Laboratory Press; all rights reserved 
Combining Mass Spectrometry (MS) and Nuclear Magnetic Resonance (NMR) Spectroscopy for Integrative Structural Biology of Protein-RNA Complexes

Alexander Leitner, Georg Dorn and Frédéric H.-T. Allain

Discovering and Mapping the Modified Nucleotides That Comprise the Epitranscriptome of mRNA

Bastian Linder and Samie R. Jaffrey
Beyond DNA and RNA: The Expanding Toolbox of Synthetic Genetics

Alexander I. Taylor, Gillian Houlihan and Philipp Holliger

\section{Structural Basis of Nuclear pre-mRNA Splicing:} Lessons from Yeast

Clemens Plaschka, Andrew J. Newman and Kiyoshi Nagai

For additional articles in this collection, see http://cshperspectives.cshlp.org/cgi/collection/

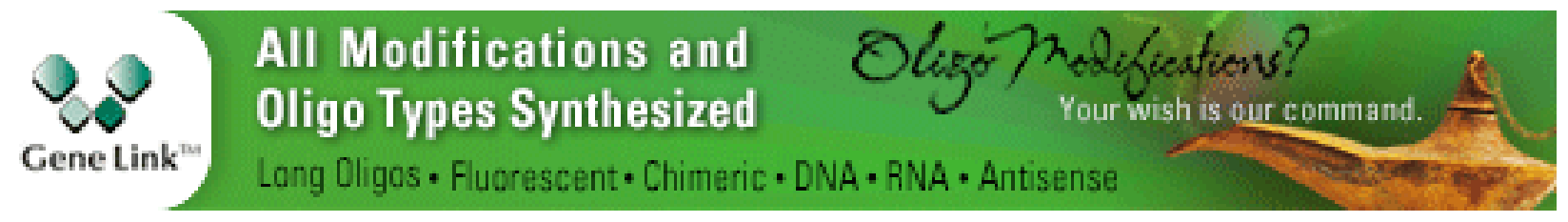

Copyright @ 2011 Cold Spring Harbor Laboratory Press; all rights reserved 